\title{
Identification of Pathogenic Leptospiral Serovars by Detection of the ompl37 Gene Using PCR
}

\section{Elaheh Rezaei (MSc)}

Department of Microbiology, Razi Vaccine \& Serum Research Institute, Agricultural Research, Education and Extension Organization (AREEO), Karaj, Iran

\section{Pejvak Khaki (PhD)}

Department of Microbiology, Razi Vaccine \& Serum Research Institute, Agricultural Research, Education and Extension Organization (AREEO), Karaj, Iran

Soheila Moradi Bidhendi (PhD) Department of Microbiology, Razi Vaccine \& Serum Research Institute, Agricultural Research, Education and Extension Organization (AREEO), Karaj, Iran

Mojtaba Noofeli (PhD)

Department of human bacterial vaccines, Razi Vaccine \& Serum Research Institute, Agricultural Research, Education and Extension Organization (AREEO), Karaj, Iran Corresponding author: Pejvak Khaki Tel: +982634502849

Email: P.khaki@rvsri.ac.ir

Address: Department of

Microbiology, Razi Vaccine \& Serum

Research Institute, Agricultural

Research, Education and Extension Organization (AREEO), Karaj, Iran

Received: 03 Jul 2018

Revised: 20 Jul 2018

Accepted: 25 Jul 2018

\section{ABSTRACT}

Background and Objectives: Leptospirosis is a widespread zoonotic disease that is transmitted directly or indirectly from animals to humans. Humans mainly acquire pathogenic leptospires through mucosal or percutaneous exposure to environment contaminated with urine from an infected animal. We aimed to identify pathogenic leptospiral serovars by detection of the ompL37 gene using polymerase chain reaction (PCR).

Methods: Sixteen pathogenic leptospiral serovars and a saprophytic serovar, $L$. biflexa were cultured in modified semisolid Ellinghausen-IlcCullough-Johnson-Harris medium containing 5\% rabbit serum. Genomic DNA extraction was done using the phenolchlorophorm method. The ompL37 gene was amplified using specific primers. PCR products were analyzed by agarose gel electrophoresis.

Results: The ompL37 gene was amplified only in the pathogenic leptospiral serovars. We detected no amplified fragment for the saprophytic serovar.

Conclusion: Leptospirosis may be confused with other infectious diseases, and therefore, its early and accurate diagnosis is crucial. We showed that molecular detection of pathogenic leptospires based on the ompL37 gene could be used for laboratory diagnosis of leptospirosis.

Keywords: Leptospirosis, PCR, ompl37 Gene, Pathogenic Leptospires.

This paper should be cited as: Rezaei E, Khaki P, Moradi Bidhendi S, Noofeli M [Identification of Pathogenic Leptospiral Serovars by Detection of the omp/37 Gene Using PCR]. mljgoums. 2019; 13(1):33-36 


\section{INTRODUCTION}

Leptospirosis is a widespread zoonotic disease caused by pathogenic leptospires (1). Over 500,000 new cases of the disease occur annually, with mortality rate of up to $70 \%$ (2). Humans mainly acquires these bacteria through mucosal surfaces and skin abrasions following contact with soil or water contaminated with urine of infected animals (3). Leptospirosis may be confused with other infectious diseases such as influenza, malaria, viral hepatitis, dengue fever and typhoid fever (4). Hence, early and accurate diagnosis of the disease is vital for proper and prompt treatment. Serological methods such as microscopic agglutination test and enzymelinked immunosorbent assay are used for diagnosis of the disease. Bacteria isolation is time-consuming and needs complex culture media (5). For this reason, polymerase chain reaction (PCR) is utilized for detection of slow-growing or fastidious microorganisms and small numbers of leptospires from clinical samples $(6,7)$. PCR has been shown to be a rapid and sensitive diagnostic method, particularly in patients with acute leptospirosis (8).

OmpL37 is a surface-exposed outer membrane protein (OMP) of Leptospira expressed during infection. This antigen has potential roles in leptospirosis, including attachment to elastinrich tissues, such as the lungs, dermis and vasculature. It has been demonstrated that the gene encoding for this protein is highly conserved in pathogenic serovars of Leptospira, and can be used for molecular detection of the disease $(9,10)$. This study aimed to detect the leptospiral ompL37 gene using PCR.

\section{MATERIALS AND METHODS}

In this study, sixteen pathogenic leptospiral serovars including: Leptospira interrogans serovars Sejroe Hardjo (RTCC2810,2821), L. interrogans Canicola (RTCC2805,2824,2836), L. interrogans Icterohaemorrhagiae (RTCC2812,2823), L. interrogans Pomona (RTCC2815,2822), $L$. Interrogans Grippotyphosa (RTCC2808,2825), L. Interrogans Autumnalis (RTCC2802), L. Interrogans Serjoe (RTCC2817), L. Interrogans Pyrogenes (RTCC2835), L. Interrogans Australis (RTCC2840), L. Interrogans Bataviae (RTCC2842), and a saprophytic serovar
Leptospira biflexa (RTCC2819) were obtained from the Leptospira reference laboratory, Razi Vaccine and Serum Research Institute, Karaj, Iran. The bacteria were inoculated into the selective culture medium EllinghausenMcCullough-Johnson-Harris medium (Difco, Sparks, USA) containing $10 \%$ rabbit serum and enrichment supplements. After 7-10 days of incubation under aerobic conditions at 28 ${ }^{\circ} \mathrm{C}$, growth was evaluated under a dark-field microscope. The samples were centrifuged at $15000 \mathrm{~g}$ for $20 \mathrm{~min}$ at $4{ }^{\circ} \mathrm{C}$. Leptospiral genomic DNA was extracted by proteinase $\mathrm{K}$ treatment and using the phenol-chloroform extraction method (11). The extracted DNA was resuspended in $20 \mu 1$ of TE buffer ( $\mathrm{pH}$ 8.0) and stored at $-20{ }^{\circ} \mathrm{C}$. Quality and quantity of the extracted DNA was then evaluated by agarose gel electrophoresis.

The ompL37 gene was amplified by PCR using the following primers: 5'-AAG GAT CCG ATC AGA TCA ACT TAG-3' (forward) and 5'-TGG GTA CCT TAA TTT TGT GTT TTT-3' (reverse) (9). For optimization of the PCR process, different concentrations of the primers $(5,10,15$ and 20 pmol) and DNA template $(0.01 \mathrm{pg}-100 \mathrm{ng})$ were used in the reactions. The final volume $(25 \mu \mathrm{L})$ of each reaction mixture contained $2.5 \mu \mathrm{L}$ of $1 \mathrm{X}$ PCR buffer, $0.5 \mathrm{mM}$ of $10 \mathrm{mM}$ deoxyribonucleoside triphosphates (dATP, $\mathrm{dCTP}, \mathrm{dGTP}$ and dTTP), $1 \mu \mathrm{M}$ of each primer, 0.75 of $50 \mathrm{mM} \mathrm{MgCl} 2,0.3$ unit $/ \mu \mathrm{L}$ of $0.5 \mathrm{Taq}$ DNA polymerase and $1 \mu \mathrm{L}$ of template DNA. The genomic DNA from $L$. interrogans serovars Icterohaemorrhagiae, Pomona and $L$. biflexa serovar Semaranga were used as positive control. A blank containing no DNA was used as the negative control. A temperature gradient was used to determine the optimal annealing temperature for the PCR assay. The PCR program was initiated at $94{ }^{\circ} \mathrm{C}$ for $5 \mathrm{~min}$, followed by 35 cycles of $94^{\circ} \mathrm{C}$ for 1 min, $53-66{ }^{\circ} \mathrm{C}$ for $1 \mathrm{~min}$ and $72{ }^{\circ} \mathrm{C}$ for $1 \mathrm{~min}$, and final extension at $72{ }^{\circ} \mathrm{C}$ for $10 \mathrm{~min}$. The PCR products were run on $1 \%$ agarose gel containing DNA safe stain and then visualized UV light.

To determine the primers specificity for the pathogenic leptospiral strains, the PCR assay was performed using specific primers for detection of the ompl37 gene in the pathogenic serovars of leptospira. DNA extracted from Salmonella enteritdis (RTCC1621) was used 
for further confirmation. In order to obtain the lowest amount of DNA for amplification and detection, concentration of an extracted DNA sample was determined using a spectrophotometer and diluted up to $0.001 \mathrm{pg} / \mu 1$.

PCR assay was eventually performed for each diluted sample.

\section{RESULTS}

The results of PCR revealed a 996 bp fragment that represented amplification of the ompl37 gene. Results of the primer sensitivity analysis also showed that the ompl37-specific primers could be amplified in DNA concentrations up to $1 \mathrm{pg} / \mu \mathrm{l}$ and are suitable for the molecular detection of pathogenic Leptospira spp. with a high sensitivity (Figure 1).

Figure 1- Results of the primer sensitivity analysis (M: $100 \mathrm{bp}$ DNA ladder, lane1: $100 \mathrm{ng} / \mu \mathrm{l}, \mathrm{lane} 2: 10 \mathrm{ng} / \mu \mathrm{l}$, lane 3: $1 \mathrm{ng} / \mu \mathrm{l}$,

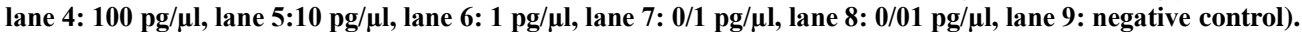

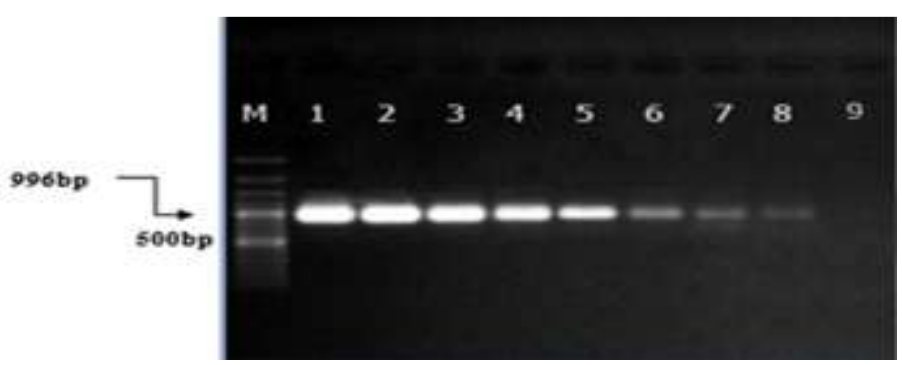

Figure 2- PCR amplification of the ompl37 gene for detection of pathogenic serovars of Leptospira (M: 100 bp DNA ladder, lane 1: $L$ L. pomona (RTCC2815), lane 3: L. biflexa, C-: negative control, C+: positive control).: canicola (RTCC2805), lane 2

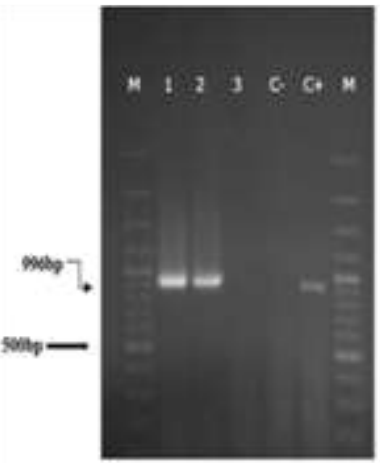

The ompL37 gene was amplified only in the pathogenic Leptospira serovars. The saprophytic serovar showed no amplified fragment (Figure 2).

\section{DISCUSSION}

Leptospirosis caused by different Leptospira species, is one of the most frequent zoonotic infections worldwide (12). It has a significant economic impact on the society and can spread from rural areas to cities (13). A major challenge in combating this disease is the application of basic research to improve diagnostics and vaccine development. Diagnosis is challenging because the available diagnostic tests are not always serovar-specific due to cross-reactivity with microorganisms in the same serogroup. Moreover, protein expression patterns in pathogenic leptospires differ when grown outside and inside the host. Therefore, the molecular mechanisms of leptospirosis pathogenesis remain unclear. Several virulence factors have been thought to contribute to the pathogenesis of leptospirosis. These include lipopolysaccharides, OMPs and other surface proteins, and adhesion molecules. Among these, OMPs may induce or enhance immune responses against the disease $(12,14)$.

Understanding the epidemiology of this disease is important for designing disease control programs. In untreated individuals, leptospirosis can progress rapidly and increase the risk of mortality, thus early diagnosis of the disease is crucial (15). PCR is more sensitive than culture for the detection of Leptospira and have been widely used for the direct detection of fastidious pathogenic microorganisms in clinical samples. Compared to other methods, PCR is more versatile for rapid diagnosis of early stages of leptospirosis (7). Ompl37 can attach to elastin in host and play a key role in the pathogenesis of leptospirosis (10). PCR targeting of the 
ompL37 gene can be useful for rapid diagnosis of the infection (16).

In the present study, we observed a $996 \mathrm{bp}$ fragment corresponding to presence of the ompL37 gene, which was absent in the saprophytic serovar. Several studies showed similar results when using other saprophytic serovars $(17,18)$.

\section{CONCLUSION}

We detected the ompL37 gene in pathogenic serovars of Leptospira using PCR. The detection of this highly conserved gene

\section{REFERENCES}

1. Haake DA, Levett PN. Leptospirosis in humans. Leptospira and leptospirosis: Springer; 2015. p. 65-97.

2. Mullan S, Panwala TH. Polymerase chain reaction: an important tool for early diagnosis of leptospirosis cases. Journal of clinical and diagnostic research: JCDR. 2016; 10(12): DC08.

3. Monahan A, Miller I, Nally J. Leptospirosis: risks during recreational activities. Journal of applied microbiology. 2009; 107(3): 707-16.

4. Plank R, Dean D. Overview of the epidemiology, microbiology, and pathogenesis of Leptospira spp. in humans. Microbes and infection. 2000; 2(10): 1265-76.

5. Picardeau M, Bertherat E, Jancloes M, Skouloudis AN, Durski K, Hartskeerl RA. Rapid tests for diagnosis of leptospirosis: current tools and emerging technologies. Diagnostic microbiology and infectious disease. 2014; 78(1): 1-8. Diagn Microbiol Infect Dis. 2014; 78(1): $1-8 . \quad$ doi: 10.1016/j.diagmicrobio.2013.09.012.

6. Lilenbaum W, Varges R, Brandão F, Cortez A, De Souza S, Brandão P, et al. Detection of Leptospira spp. in semen and vaginal fluids of goats and sheep by polymerase chain reaction. Theriogenology. 2008; 69(7): 837-42. doi: 10.1016/j.theriogenology.2007.10.027.

7. Hoseinpur R, Khaki P, Noofeli M, Bidhendi S. Molecular detection of pathogenic leptospiral serovars by PCR, based on lipL21 gene. Archives of Razi Institute. 2016; 70(4): 223-7.

8. Azizi S, Kheirandish R, Rahimi E. Comparison of polymerase chain reaction and Warthin-Starry techniques to detect Leptospira spp. in kidneys of slaughtered cattle. Onderstepoort J Vet Res. 2014 ; 81(1): e1-e6. doi: 10.4102/ojvr.v81i1.821.

9. Oliveira TL, Grassmann AA, Schuch RA, Neto ACPS, Mendonça M, Hartwig DD, et al. Evaluation of the Leptospira interrogans outer membrane protein OmpL37 as a vaccine candidate. PloS one. 2015;10(11):e0142821.

10. Pinne M, Choy HA, Haake DA. The OmpL37 surface-exposed protein is expressed by pathogenic Leptospira during infection and binds skin and vascular elastin. PLoS Negl Trop Dis. 2010; 4(9): e815. doi: 10.1371/journal.pntd.0000815. could be useful for identification of pathogenic Leptospira and early diagnosis of leptospirosis.

\section{ACKNOWLEDGMENTS}

We would like to thank the staff of the Leptospira reference laboratory and Department of Microbiology in Razi Vaccine and Serum Research Institute, Iran.

\section{CONFLICT OF INTEREST}

The authors declare that there is no conflict of interest.

11. Sambrook, J., \& Russell, D. W. Rapid isolation of yeast DNA. Cold Spring Harbor Protocols. 2002; (1), pdb. doi:10.1101/pdb.prot4039.

12. Langston CE, Heuter KJ. Leptospirosis: A reemerging zoonotic disease. Vet Clin North Am Small Anim Pract. 2003; 33(4): 791-807.

13. Schneider MC, Jancloes M, Buss DF, Aldighieri S, Bertherat E, Najera P, et al. Leptospirosis: a silent epidemic disease. Int J Environ Res Public Health. 2013; 10(12): 7229-7234. doi: 10.3390/ijerph10127229.

14. Fraga T, Barbosa A, Isaac L. Leptospirosis: aspects of innate immunity, immunopathogenesis and immune evasion from the complement system. Scand J Immunol. 2011; 73(5): 408-19. doi: 10.1111/j.13653083.2010.02505.x.

15. Helmerhorst H, Van Tol E, Tuinman P, De Vries P, Hartskeerl R, Grobusch M, et al. Severe pulmonary manifestation of leptospirosis. Neth J Med. 2012; 70(5): 215-21.

16. Majed Z, Bellenger E, Postic D, Pourcel C, Baranton $\mathrm{G}$, Picardeau M. Identification of variable-number tandem-repeat loci in Leptospira interrogans sensu stricto. J Clin Microbiol. 2005; 43(2): 539-45.

17. Slack A, Symonds M, Dohnt M, Smythe L. An improved multiple-locus variable number of tandem repeats analysis for Leptospira interrogans serovar Australis: a comparison with fluorescent amplified fragment length polymorphism analysis and its use to redefine the molecular epidemiology of this serovar in Queensland, Australia. J Med Microbiol. 2006; 55(Pt 11): 1549-57.

18. Slack AT, Dohnt MF, Symonds ML, Smythe LD. Development of a multiple-locus variable number of tandem repeat analysis (MLVA) for Leptospira interrogans and its application to Leptospira interrogans serovar Australis isolates from Far North Queensland, Australia. Annals of clinical microbiology and antimicrobials. 2005;4(1):10 
. 